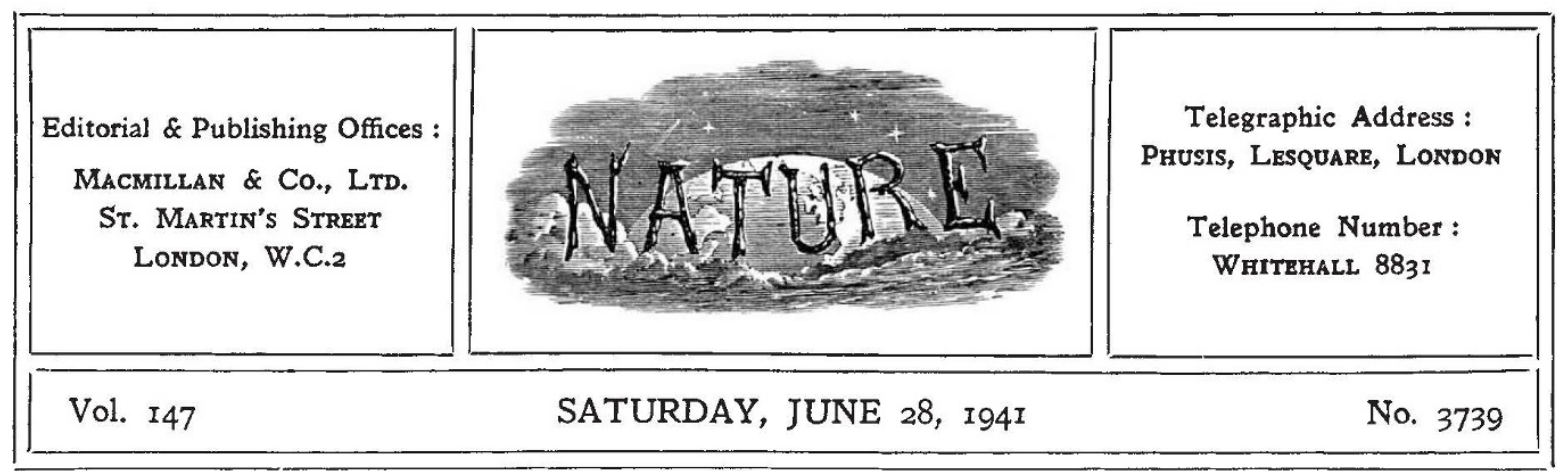

\title{
LE COQ D'OR
}

$\mathrm{K}^{\mathrm{N}}$ ING DODON was mighty anxious. His kingdom was threatened, yet though in his youth and prime he was a redoubtable monarch, he had long since ceased to care for warlike pursuits. Following the example of their monarch, the people too were contemptuous of the profession of arms, and their young men gave themselves up to pleasure.

The rulers of neighbouring domains were not slow in taking advantage of this state of affairs, so now here was King Dodon threatened with the dangers of invasion. In council, Prince Guidon advised his father. "The chief of our troubles," he said, "is that our enemy is so near to us that he is already about to fall upon our army and annihilate it. Let us, then, bring back our warriors from the borders and place them around our beloved capital to protect it and ourselves from harm."

All the company were delighted, except Prince Afron and the venerable head of the army, Polkan. They angrily opposed such a foolish plan. So King Dodon asked the advice of his son Afron who said: "Recall our soldiers just a month before the enemy attacks, and then we will go forth and crush him."

With all this conflicting advice, no wonder King Dodon was puzzled, and it is not surprising that disorder broke out in the company of the Council.

Then in the midst of this confusion there appeared at the top of the stairway a very old and venerable-looking Astrologer. He carried in one hand an astrolabe and in the other a bag. "Hail, King Dodon! Although thou knowest not me, yet art thou well known to me. . . . I have come to offer unto thee a magic remedy, so that thou mayest once more sleep in peace... .
Accept my Golden Cockerel, O Sire, and place it upon the highest spire upon thy palace; and it shall be a true watchman unto thee. When all is peaceful and quiet, it will make no sound whatever . . .; but if enemies are about, or if thy peace is threatened in any way, then will my magic Golden Cockerel raise his comb, flap his wings, and turning in the direction from whence the danger appears, will crow aloud 'Cock-adoodle-do! Beware!" "

That is how the story of Rimsky-Korsakov's pantomime-opera "Le Coq d'Or" opens. It does not tell us how old that Golden Cockerel was, nor for how many years the Astrologer had possessed it; but six years ago another 'Golden Cockerel' began to develop, and now, having proved its ability to call "Cock-a-doodle-do! Beware!" at the appropriate moment, it, together with its 'Astrologer', was introduced to the world by a Minister of State on June 18, 1941.

But there is nothing very new in this announcement and appeal, both at home and overseas, for radio engineers, physicists, etc., to play their part in helping the Cockerel to crow. That is, it is not very new to mon of science. Radiolocation, in its origin, was the conception of one man, Mr. R. A. Watson Watt, C.B., F.R.S., scientific adviser on telecommunications to the Chief of the Air Staff, who, with his collaborators and assistants, aided it in its development from chick to adult. No; neither the Cockerel nor its Astrologer are very new to science, for Watson Watt's researches in radio engineering, especially while at the National Physical Labora. tory and at the Bawdsey Research Station, have earned for him a world-wide reputation among men of science, and he is the author of many contributions which have appeared in our columns 
The Astrologer said : "Although thou knowest not me, yet art thou well known to me." How true has that been in modern times. How pitifully few of the people, and especially of their leaders, have even bothered to examine what Science has to offer them; and how few are there who know, or express appreciation of, the work of Science behind all the advances-technical, biological, medical, etc.- of this age. It is necessary for national emergencies and modern 'Astrologers' to bring it all home to them. Lord Beaverbrook, on the occasion of the announcement of Watson Watt's great achievement, has now impressed it upon the people that "Technical developments make progress in war which sometimes outstrips all that has gone before. . . . It is the scientist who will heal our wounds. It is the scientist who will protect us against the loss of our life-blood. It is the scientist who will save our home and guard our hearthstones."

Thus on the basis of the work of Watson Watt, Sir Frank Smith and others, did the Minister of State make his call to service: "Man the front line of Science." No doubt men and women from all parts of the world will respond to the call, and thus will Science have made in an almost glamorous way another of her many contributions towards victory in war, for truly this is not only a war of machines-for that is only a part of the story; it is a war of Science, the science of defence, the science of living against great odds, and, alas, the science of destruction.

But what is to be the result of all this? What did the Astrologer demand in the end? He declared that the ordinary gifts of riches and high rank were as nothing to him, since he regarded love only as precious, and at the end of the story he demands the hand of the Queen of Shemakhan. So this is where modern Science and the ancient Astrologer must part company.

Through such men as Watson Watt, the people are learning the first-rate value of Science in modern warfare; so now let Science build up evidence for her claim for all-out recognition and for her just status in times of peace.

How often has this been emphasized in Nature. But society has still to realize it fully. Even in medicine most people recognize only the medicine of disease. Either they do not recognize or they ignore the medicine of health. They recognize the work of a medical man only when, through illness, they need him. Little do they know of preventive medicine. So is it with Science. Science can be constructive as well as destructive. Which it is to be depends upon society. She offers us a good, strong, useful rope ; is it her fault if we choose to hang ourselves with it? Science has played and will have to play, a very important part in the advancement of civilization and the improvement of social life. Little have men of affairs realized or recognized this in the past.

In his appeal, Lord Beaverbrook referred to "the hour when men of science can turn again to the thoughts and the labours of peace". The exigencies of war have constrained many men of affairs to recognize and to appreciate what Science has to offer. The War Minister, too, announced to the House of Commons on June 18 that there might be occasion for the appointment of a special scientific attaché to foreign Governments in view of what Lord Beaverbrook had said in his broadcast appeal. But Science offers more, much more, than weapons of destruction and materials for defence. She offers a horn of plenty, full of good, constructive ideas and machines. When the hour of peace comes, is she to be discarded as something only useful in confounding our enemies? Are Mr. Eden's attachés to be recalled? If so, then our men of affairs will prove to have been opportunists who have learned nothing.

Our Army, Air Force and Navy are in the front line of action. But there are many other frontsour kitchens, gardens, farms and factories-and not least of all, Science. We have learned of the folly of neglecting our fighting forces in those times of peace when certain sections of the world were treating a period of peace as one of preparation for war. Until the world is ready for a real and lasting peace, we must bear that lesson in mind, once victory is achieved. This applies also to Science. Let her be recognized and encouraged in the everyday lives of the many; let her too be admitted to the council of the chosen few. Never let her be neglected or merely taken for granted again.

Men of science are becoming very conscious of their duty to society. Will society, in the peace to follow, recognize its obligations to Science and avail itself of all the good things that this war is proving Science has to offer? Men of science will be able to offer new and possibly strange tools to society; will society take them and tackle the job of building and maintaining the peace-a job infinitely more difficult than that of winning the war?

"The scientist will heal our wounds." 